\title{
Entre o campo e a mina: valores e hibridações nas trajetórias de mineiros de carvão no sul do Brasil ${ }^{*}$
}

\author{
Marta Cioccari**
}

Resumo: Por meio da análise de narrativas de trabalhadores na mineração de carvão na região do Baixo Jacuí, no Rio Grande do Sul, cujas trajetórias transitam entre o urbano e o rural, sugiro a existência de múltiplas concepções de honra nesse contexto, relacionadas, sobretudo, ao caráter trágico da profissão, à militância sindical e aos jogos que caracterizam amplamente as relações dos mineiros com sua atividade. Nesse universo - em que a mina de subsolo foi desativada em 2002 - emergem nos relatos, junto ao orgulho do "trabalho bem feito" e à exaltação das competências profissionais e da "coragem" para enfrentar patrões e chefias, manifestações que destacam a "esperteza", a "ousadia" e a própria arte da malandragem, espécie de anti-honra que pode ser fonte de prestígio e de reconhecimento. As concepções que remetem às formas locais de construção da sua dignidade convivem com a representação em torno da "grande honra" da profissão, a imagem pública de heroísmo que carregam os trabalhadores das minas subterrâneas em diferentes lugares do mundo.

Palavras-chave: mineiros de carvão; honra; etnografia.

Abstract: By analyzing narratives of workers in coal mining in the region of Lower Jacuí in Rio Grande do Sul, whose trajectories pass between urban and rural,

* Este artigo condensa aspectos da minha tese de doutorado, desenvolvida sob a orientação do professor José Sergio Leite Lopes, no PPGAS, Museu Nacional, UFRJ. Agradeço a José Sergio, entre outros interlocutores, pelo permanente estímulo. Para um aprofundamento, ver: CIOCCARI, Marta. "Do gosto da mina, do jogo e da revolta: um estudo antropológico sobre a construção da honra em uma comunidade de mineiros de carvão". (Tese de Doutorado em Antropologia Social, Museu Nacional, UFRJ, 2010). Certos elementos também constam da dissertação de mestrado, defendida no PPGAS, UFRGS, sob a orientação da professora Cornelia Eckert. Ver: CIOCCARI, Marta. Ecos do subterrâneo: cotidiano e memória em uma comunidade de mineiros de carvão. 2. ed. Rio de Janeiro: iVentura, 2015. E, ainda: CIOCCARI, Marta. "Aspectos da construção da honra entre mineiros de carvão em uma comunidade no sul do Brasil”. Revista Theomai (En línea), v. 24, p. 141-165, 2012; CIOCCARI, Marta. "Risco, riso e respeito: notas sobre a construção da honra entre os trabalhadores nas minas de carvão no Brasil e na França”. Revista Brasileira de História \& Ciências Sociais, v. 3, p. 17-27, 2011. Agradeço aos editores do presente dossiê, especialmente à colega Clarice Speranza, assim como as preciosas contribuições dos pareceristas. Minhas pesquisas foram conduzidas com apoio do CNPq e da Capes.

** Mestre em Antropologia Social pela UFRGS e doutora em Antropologia Social pelo Museu Nacional, UFRJ. Atualmente é Professora Adjunta do Departamento de Ciências Sociais da UFRRJ. É subcoordenadora do Núcleo de Antropologia do Trabalho, estudos biográficos e de trajetórias (NuAT), do PPGAS, Museu Nacional, UFRJ. 
suggest the existence of multiple honor of conceptions in this context, related mainly, the tragic character of the profession, trade union militancy and games that broadly characterize the relations of miners with their activity. In this universe - in the underground mine was shut down in 2002 - emerged in the reports, with the pride of "job well done" and the exaltation of professional skills and "courage" to face bosses and managers, events that highlight the "smarts "the" boldness "and the very art of trickery, a kind of anti-honor that can be a source of prestige and recognition. The conceptions that refer to local construction forms of their dignity coexist with representation around the "great honor" of the profession, the public image of heroism that carry workers in underground mines in different parts of the world.

Keywords: coal miners; honor; ethnography.

\section{A etnografia num mundo urbano e rural}

Quando fui morar na cidade de Minas do Leão (RS) para uma pesquisa etnográfica em 2006, pude perceber que, sob uma retórica coletiva que expressava uma sociedade cordial e unida, era possível notar várias outras tessituras, nenhuma delas menos verdadeira, mas cada qual engendrando sua própria intriga. Passei então a considerar com atenção o que me disse certa vez um trabalhador: "Aqui nada do que parece é". Para entender as relações construídas nessa localidade, era importante considerar a definição usada por um mineiro para falar da atividade exercida nos subterrâneos escavados sob a cidade: "A mina é uma caixa de segredos que ninguém consegue descobrir o significado". Entre as metamorfoses que se vinculam ao aprendizado do mineiro de subsolo - como nos ensinam as memórias que evocam o período de funcionamento da mina de subsolo - está aquela que liga o mundo da superfície (relativo ao universo social e familiar) ao mundo das entranhas da terra (relacionado à rotina de trabalho). Nesse contexto, há outras metamorfoses, individuais e sociais, por vezes menos visíveis. Uma delas diz respeito aos deslocamentos e hibridações entre o urbano e o rural.

Minas do Leão (RS), cidade erguida na esteira da mineração de carvão e dividida ao meio por uma rodovia federal, a BR 190, sempre teve uma vida partida e, em certa medida, misturada, sob vários aspectos. Uma dessas divisões diz respeito aos limites, trânsitos e fronteiras entre espaços sociais e geográficos, entre ocupações e entre valores herdados da origem camponesa e os que se afirmaram junto com a atividade de exploração mineral. No período da pesquisa, dos quase 8 mil habitantes, $95,72 \%$ viviam na área urbana do município e 4,28\% na área rural. ${ }^{1}$ O núcleo urbano, construído em torno das minas de carvão, é cercado por áreas rurais e por florestas de eucaliptos e de acácias. Na época de funcionamento da mina de subsolo, a madeira era usada para o escoramento das galerias; mais recentemente, alimenta fábricas de papel e celulose da região. Com uma área de 426,2 quilômetros quadrados, o espaço do município é ocupado em sua maior parte pela zona rural onde se desenvolve a pecuária, com o gado de corte que povoa os campos das médias e grandes propriedades, e a agricultura, com destaque para o cultivo do arroz, da soja e da melancia. Não só grande parte das famílias mineiras tem origem rural como muitas mantinham as duas atividades paralelamente

1 Dados do último Censo do IBGE. 
ou de modo intercalado, seguindo-se à aposentadoria na mina uma retomada da atividade agrícola.

Com a retração da atividade carbonífera e o encerramento da extração de subsolo da empresa estatal Companhia Riograndense de Mineração (CRM) na principal mina da localidade, a Leão I, ocorrido em 2002, muitos filhos de mineiros, sem encontrar postos de trabalho nas indústrias da região, lançaram-se ao trabalho rural ou ao "corte de mato", empregados muitas vezes por empresas clandestinas. Estudos têm alertado para os problemas sociais e ambientais derivados das plantações de eucaliptos. Além de uma significativa mudança na paisagem, notamse transformações no modo de vida dos descendentes de famílias mineiras.

Importa assinalar que ali o urbano e o rural convivem, interpenetram-se e determinam uma mescla de hábitos e de valores. Costumes que caracterizam comunidades rurais têm nesse contexto uma forte expressão, como as relações de compadrio e de patronagem, ou seja, relações de poder alicerçadas em relações pessoais. A dimensão do compadrio está, como na definição de Pitt-Rivers², imbricada com uma concepção de amizade inaugurada ou reforçada por algum "favor" ou "ajuda", na linguagem local. As relações de compadrio são referidas livremente e podem ser lidas nos principais acontecimentos sociais, enquanto que a patronagem manifesta-se tanto na forma de "cunhas" como na "ajuda" financeira ou na prestação de favores em troca de apoio eleitoral. Esses laços contratuais se aproximam, em certa medida, da forma encontrada por Foster (1967) em seus estudos no México. ${ }^{3}$

Na região, adota-se o termo "cunha", equivalente a "pistolão", para dizer que sempre se depende de alguém influente, de "boa cunha" para obter um emprego, uma bolsa de estudos para o filho, uma vaga no time de futebol. "Cunha", segundo me explicava o ex-mineiro Adão Souza, é a relação com alguém que "ajude" a pessoa. Assim, para obter um emprego, conforme observava, "é preciso ter uma cunha muito boa, senão não pega. Tem que ter as cunhas, tem que ter enjambração, senão não pega". O ex-mineiro Luiz Marino esclarecia que a "cunha" é o pedaço de madeira que serve para apertar os quadros das galerias subterrâneas. Sublinhava que "cunha é o que ajuda o outro" como a madeira "ajudava" na segurança do teto da mina. Sua definição, baseada na experiência de trabalho como madeireiro no subsolo, é eficaz para nomear essas relações e não destoa da definição dos dicionários.

Na mesma perspectiva de Olivier Schwartz ${ }^{4}$, considero que a mina de carvão não é somente um dado econômico, mas o que se poderia chamar de um "fato social total", seguindo a definição de Marcel Mauss. ${ }^{5}$ Ou seja, compreende todo um mundo de relações, fortemente firmadas sobre si, marcando de forma intensa a incorporação pelos mineiros de seu métier, dizendo respeito - como no conceito de habitus adotado por Bourdieu - a disposições interiorizadas e condições objetivas, que determinam certa héxis corporal, formas de se portar e de expressar uma

2 PITT-RIVERS, Julian. "Friendship and Authority". In: of Chicago Press, 1971, p.137-160.

The People of the Sierra. London: The University

3 Ver: FOSTER, George. "The dyadic contract: a model for the social structure of a Mexican peasant village". In: POTTER, J. M. et al. (orgs.) Peasant Society: a reader. Boston: Litle Brown, $7^{a}$ ed., 1967, p. 213-230; e, ainda: FOSTER, George. "La sociedad campesina y la imagem del bien limitado". In: WAGLEY, Charles et al. Estudios sobre el campesinato latinoamericano: la perspectiva de la antropología social. Buenos Aires: Ediciones Periferia, 1974.

4 SCHWARTZ, Olivier. Le monde privé des ouvriers: hommes et femmes du Nord. Paris: PUF, 1990, p. 11-12.

5 MAUSS, Marcel. Ensaio sobre a dádiva. Lisboa: Edições 70, 2001. 
relação com o mundo. ${ }^{6}$ Num artigo a propósito da obra Mineur de fond 7 , Georges Balandier mencionava que, para o mineiro, a mina é "sua cidade, é todo um mundo, uma espécie de ilha negra"8 de forma que os trabalhadores estão ligados entre si por meio da honra da corporação ${ }^{9}$ e solidariedade face aos riscos, mantendo com seu ofício uma relação passional.

Schwartz evidenciou o modo pelo qual, da metade do século XIX até a metade do século XX, a mina de carvão se impôs como atividade e referência hegemônica na França, um fenômeno que teve lugar sob o impulso das companhias privadas que partilhavam, sob a concessão do Estado, a exploração das reservas carboníferas. Dispostas a fixar uma população de mineiros e em investir em sua reprodução social, as companhias utilizaram toda a gama de meios caracterizando políticas paternalistas. Esses esforços se dirigiam ao trabalho, mas também à vida cotidiana, à família, à educação, à moral e à religião. As cidades mineiras, com suas aglomerações de pequenas casas individuais, tornaram-se progressivamente parte da paisagem em vários países, inclusive no Brasil. Assim, emergiram as comunidades mineiras, entrecruzando efeitos de uma política patronal com as lutas operárias para se apropriar das condições necessárias à sua existência. ${ }^{10}$

A vila operária de Minas do Leão (RS) surgiu a partir da década de 1940 em torno da operação das minas de subsolo pelo Estado. Num mercado dividido com empresas privadas, o governo estadual atuava por meio do Departamento Autônomo de Carvão Mineral (DACM), que se tornou Companhia Riograndense de Mineração (CRM), em 1969. Como no caso europeu, as empresas carboníferas ofereciam atrativos para obter a adesão de novos trabalhadores, sob a forma de moradias e salários superiores aos de outros operários. Esses "tempos de fartura" são evocados na memória dos moradores, em contraste com o tempo de crise e desemprego do presente. Com o encolhimento do mercado para o carvão, a CRM reduziu drasticamente o número de trabalhadores nas últimas décadas. ${ }^{11}$ Limitava-se, em 2004, a menos de 100 trabalhadores em Leão I, depois de ter empregado 1.100 na chamada "fase áurea" de produção, entre 1978 e 1994. Em janeiro de 2006, quando voltei à comunidade, percebi que as - já surradas - esperanças em torno de um novo ciclo para a mineração subterrânea de carvão haviam estranhamente se reacendido, como numa espécie de eterno retorno. As conversas nas casas tinham mudado, desde minha visita anterior, da tristeza e do nostálgico lamento do fim da mina, ${ }^{12}$ com o temor do desaparecimento do ofício de mineiro, a uma nova aposta gerada pelos desdobramentos de um arrendamento feito pelo Estado a uma mineradora privada de Criciúma (SC) para a conclusão da mina de

6 BOURDIEU, Pierre. A dominação masculina. Rio de Janeiro: Bertrand Brasil, 1999.

7 Título da obra autobiográfica do ex-mineiro francês Augustin Viseux. Ver: VISEUX, Augustin. Mineur de fond, Paris: Plon, 1991.

8 No original: [A mina é] "sa ville, c'est tout un monde, une sorte d'île noire". Cf. BALANDIER, Georges. "Histoire de vie, modo d'emploi". Le monde, Paris, 28 juin., 1991, p. 22.

9 Ver: MOORE JR, Barrigton. “Militância e apatia no Ruhr antes de 1914”. In: __ . Injustiça: as bases da obediência e da revolta. São Paulo: Brasiliense, 1987. O autor considera que, no Ruhr, o principal centro da mineração de carvão alemã, até as primeiras décadas do século 20, os mineiros não desenvolveram sentimentos expressivos de injustiça em relação à sua situação devido ao seu orgulho e senso de honra, como "membros de uma corporação profissional de status reconhecido na ordem social" 1987, especialmente (p. 317-325).

10 SCHWARTZ, Olivier. Le monde privé des ouvriers: hommes et femmes du Nord. Paris: PUF, 1990, p. 12.

11 O encolhimento da estatal abriu espaço para o crescimento da principal concorrente privada, a Copelmi, sediada em Butiá, atualmente operando minas de superfície.

12 Em 2003, velhos mineiros diziam não ter mais esperanças na exploração do carvão: "Tanta promessa que houve... e em cada época de política, a primeira coisa que eles lembram é da mina. É triste”. Nas falas, cidade e mina pareciam estar dissolvidas na mesma decadência, no mesmo ato de desaparecimento: "Minas do Leão, aqui, morreu. Não vai mais existir Minas do Leão, mineração não". 
Leão II. Quando da implantação parcial, na década de 1980, essa mina era considerada a mais moderna da América Latina. ${ }^{13}$ Ora um trabalhador em extinção, ora um ser moderno, o mineiro continuava a encarnar uma controvertida heroicidade e formas específicas de uma honra do trabalho.

Minas do Leão situa-se a 80 quilômetros de Porto Alegre, na região centrosul do Rio Grande do Sul, às margens da BR 290, que conduz à fronteira oeste do estado e à Argentina. O município pertence à Microrregião Carbonífera do Baixo Jacuí, que reúne várias cidades desenvolvidas na esteira da mineração de carvão e que, nas últimas décadas, enfrentam o empobrecimento causado pela decadência da extração mineral. Entre 1940 e 1991 ocorreu um processo acelerado de urbanização nessa região, chegando a 146.480 pessoas vivendo nos limites urbanos das sedes desses municípios. O período mais expressivo de migrações para a localidade de Minas do Leão ocorreu entre 1940 e 1970. Nos anos 1940 a mineração atraiu trabalhadores de diversas áreas do estado, promovendo uma urbanização acelerada e um rápido crescimento da população. Como mencionado, as empresas carboníferas ofereciam atrativos para obter a adesão de novos trabalhadores, como moradias e serviços de saúde, além de salários superiores aos de outros segmentos para quem trabalhasse nas galerias subterrâneas. Naquela época, Minas do Leão era um povoado pertencente ao município de São Jerônimo, guindado à categoria de distrito em 1960. Em 1992 tornou-se município ao emancipar-se de Butiá. Desde meados dessa década, a extração de carvão na região veio enfrentando forte retração, apesar das reservas de cerca de 200 milhões de toneladas na bacia carbonífera.

Ainda que o local que hoje abriga o atual município de Minas do Leão (RS) estivesse no epicentro das descobertas de carvão no estado, entre o final do século XVIII e o começo do século XIX, a produção em escala só se desenvolveria ali um século mais tarde, intensificando-se após o esgotamento das jazidas em Arroio dos Ratos, o berço da mineração gaúcha. Ao longo de um século, mineiros, técnicos, especialistas e engenheiros estrangeiros - ingleses, alemães, espanhóis, portugueses, poloneses, ucranianos, russos, iugoslavos, austríacos, entre outros tiveram papel relevante não apenas nas sondagens, mas também na produção em escala. Os trabalhadores imigrantes aportaram à região desde meados do século XIX, com sua experiência na mineração de subsolo na Europa representando ela mesma numa espécie de "grande honra" aos olhos do Império brasileiro e, posteriormente, das companhias carboníferas. Carregavam consigo também uma respeitável experiência em mobilizações operárias, aprendida em seus países de origem. Assim como os ativistas brasileiros das organizações de esquerda, principalmente do PCB, muitos desses imigrantes, considerados anarquistas e socialistas, ajudariam a forjar valores de resistência e de autoestima entre os mineiros, paralelamente à construção de uma "honra militante", ambas situadas na contramão do que seria desejável pelas companhias, que exigiam de seus trabalhadores disciplina, docilidade e obediência. ${ }^{14}$

13 Projetada por engenheiros ingleses, Leão II recebeu um investimento de US\$ 70 milhões na implantação de 8,5 quilômetros de espaçosas galerias escavadas a 180 metros de profundidade. Sua retomada, evocada em períodos eleitorais, sempre navegou ao sabor das políticas, na dependência de garantia de "um mercado para o carvão", um discurso que, neste contexto, significa a conclusão da usina de Jacuí l, em Charqueadas, cuja obra foi interrompida devido a problemas ambientais.

14 Essas informações foram obtidas em documentos do antigo Cadem, mantidos na época por uma historiadora local, em Butiá. Apesar da má conservação, era possível se obter dados sobre as condições de vida e de trabalho dos mineiros entre as décadas de 1920 e 1960. Atualmente, esses documentos encontram-se reunidos no Museu Estadual do Carvão, em Arroio dos Ratos (RS). Também pesquisei fichas funcionais nos arquivos da CRM, nas quais se pode obter indicações sobre promoções e punições dos 
Esses imigrantes perderam rapidamente, aos olhos patronais, parte do prestígio ao se negarem ao trabalho, ainda na chegada, solidarizando-se com os companheiros em greve, ou quando, já estabelecidos, participavam da organização dos movimentos. Certos estrangeiros, especialmente os poloneses, passaram da condição de valorizados por sua experiência a indesejáveis, ainda que fossem reconhecidos pelas empresas como "trabalhadores", competentes e conhecedores dos meandros da profissão. À medida que se esboçou um sentimento de dignidade da categoria, com as vitórias obtidas nos movimentos, esvaziaram-se as construções em torno de sua suposta abnegação e docilidade. As imagens que aparecem nos documentos das empresas para justificar a necessidade de contratação de operários estrangeiros fazem referências ao desinteresse, à preguiça, à falta de responsabilidade dos trabalhadores locais do que seriam provas as altas taxas de absenteísmo e a baixa produção - com menções ainda às violências de que seriam capazes nas paralisações. Em contraponto a isso, o ex-mineiro Jover Telles sustentava que, submetidos a condições de trabalho que eram "as piores possíveis", os operários das minas gaúchas ainda obtinham uma produtividade "espantosa". ${ }^{15}$

Diferentemente de outras vilas operárias abordadas pela literatura antropológica, em que a cidade ou comunidade se constrói em torno de uma única empresa, Minas do Leão nunca teve esse caráter monolítico, mesmo que a estatal CRM tenha sido na maior parte do tempo o principal poder local. ${ }^{16}$ Ao longo de sua história a localidade foi palco de uma série de outros empreendimentos, tanto da privada Copelmi (sucessora do Consórcio Administrador das Empresas de Mineração, Cadem), sediada em Butiá, que mantinha ali a Mina do Recreio, como também da Mina de São Vicente ou Mina do Alencastro, de menor porte. Havia, portanto, uma diversidade de poderes que se mesclaram na vida local, demarcando diferentes espaços sociais e geográficos, com as oposições entre os bairros Recreio e Leão (ou Centro), como se fossem duas vilas operárias, dois núcleos urbanos formados em torno de diferentes minas, gerando tensões, hostilidades e disputas, das quais uma das mais expressivas parece ter sido a rivalidade entre as equipes de futebol operário Olaria (formada em torno da mina de Alencastro, no Recreio) e Atlético (constituído em torno da CRM, no Centro), que se mantém até os dias atuais. ${ }^{17}$

Moradores de Minas do Leão definem a cidade como "quase uma vila”. Com um desenho estreito e alongado, o núcleo urbano distribuído em duas longas avenidas e dezenas de ruas secundárias. Praticamente todas as casas têm apenas um pavimento. Chamam atenção os tons vivos que colorem a maior parte das

trabalhadores. Para uma perspectiva histórica sobre os conflitos enfrentados pela categoria na região, recomendo: SPERANZA, Clarice Gontarski. Cavando direitos: as leis trabalhistas e os conflitos entre os mineiros de carvão e os seus patrões no Rio Grande do Sul (1940-1954). Porto Alegre: Anpuh/Oikos, 2014. 15 TELLES, Jover. O movimento sindical no Brasil. Rio de Janeiro: Editorial Vitória, 1962.

16 Para um aprofundamento da noção de vila operária no setor têxtil, ver: LEITE LOPES, José Sergio. A Tecelagem dos Conflitos de Classe Na Cidade das Chaminés. São Paulo: Marco Zero; Brasília: Ed. UnB, 1988; "Memória e transformação social: trabalhadores de cidades industriais". Mana (UFRJ. Impresso), v. 17, p. 583-605, 2011; LEITE LOPES, José Sergio; ALVIM, Rosilene. "Vila Operária e Cidadania”. Sociologia e Política, Curitiba, v. n. 2, 1994; __ . "Uma memória social operária forte diante de possibilidades difíceis de patrimonialização industrial”. In: GRANATO, Marcus; RANGEL, Marcio F. (Org.). Cultura Material e Patrimônio da Ciência e Tecnologia. Rio de Janeiro: MAST, 2009.

17 Sobre esse aspecto, ver: CIOCCARI, Marta. "Mina de jogadores: o futebol operário e a construção da 'pequena honra”. Cadernos Arquivo Edgard Leuenroth (UNICAMP), v. 16, p. 76-115, 2011. E ainda: CIOCCARI, Marta. "Football in the Rio Grande do Sul Coal Mines". In: Fontes, Paulo; Holanda, Bernardo Buarque. (Org.). The Country of Football: Politics, Popular Culture, and the Beautiful Game in Brazil. London: Hurst, 2014, p. 67-85. 
moradias, pintadas de azul, rosa, verde, amarelo ou outras cores. Há um número menor de velhas casas de madeira sem pintura, que guardam características da antiga vila mineira. Os principais estabelecimentos estão situados ao longo da Avenida Getúlio Vargas. Ali estão a prefeitura, a sede da CRM, o sindicato dos mineiros, pelo menos cinco das cerca de 10 igrejas locais (como a católica e algumas protestantes), farmácias, as principais lojas e supermercados, o Clube Duque de Caxias, uma escola, a delegacia de polícia e a Brigada Militar. Essa avenida é conhecida entre os moradores como "a rua de cima", enquanto que a Avenida Alberto Pasqualini é considerada a "rua de baixo". Nesta última, estão localizados a estação rodoviária, o posto de saúde, um campo de futebol, outras igrejas evangélicas e casas de comércio, principalmente minimercados. Além das duas longas avenidas, são 112 ruas, três estradas e 15 becos, espalhados pelos bairros Centro, que entorna as minas da CRM (Leão I e Leão II), Santa Albina e São Miguel, localizados à direita da BR 290 (no sentido de quem chega da capital), e os bairros São José, Recreio e Coréia, à esquerda da rodovia, chamados de vilas, com condições socioeconômicas mais precárias.

Nessa cidade erguida em torno da atividade industrial, diferentes dimensões da natureza convivem com a urbanização, exibindo relações próximas, e até mesmo complementares, entre homens e animais. Os cães, possíveis descendentes daqueles que, no passado, acompanhavam as caçadas promovidas por seus donos nas horas de folga da mina, costumam andar em bandos pelas ruas e fazer sinfonias à noite. Latidos e uivos de todos os timbres são mantidos por horas a fio, quase coincidindo com o canto dos galos, geralmente descompassado entre madrugadores e retardatários. Raro é o dia em que não se avistam cavalos pastando na grama que cresce no espaço que seria reservado às calçadas, junto ao meio-fio. Embora ainda haja grande número de cavalos para "carreiras"18 e alguns usados no cultivo da terra, a maioria desses animais tem uma "ocupação" urbana: puxam carroças usadas no transporte de móveis e mudanças, os "fretes", com os quais alguns ex-mineiros complementam a sua aposentadoria, cobrando valores extremamente baixos para um serviço de responsabilidade. ${ }^{19}$

Mais de uma vez, durante a etnografia, assisti a cenas em que um desses cavalos soltava-se da carroça e avançava em alta velocidade, lançando o móvel transportado ao chão. Nessas ocasiões, toda a vizinhança saía à rua para acompanhar o incidente. Os donos reprendiam severamente os animais, considerando não apenas o prejuízo financeiro, mas também moral, já que o "cliente" poderia se revoltar e exigir o ressarcimento. E o que é pior: podendo o episódio gerar uma inimizade entre vizinhos, parentes ou antigos colegas, dependendo do valor do bem transportado e do estado ao qual ficou reduzido com a desabalada carreira e a queda. Parte da indignação dos donos vinha do fato de considerarem esses animais "domados". Como se verá, essa mesma expressão - "domados" ou "não domados" - era usada pelos mineiros para se referir aos trabalhadores rurais que deixavam as lides do campo para se empregarem na mina. Esses também eram considerados "quase como animais", "selvagens", "xucros" e que precisavam ser "domados", disciplinados tanto pelo sistema industrial como pela cultura operária, marcada pelos valores da esperteza e da malandragem.

18 Corridas de cavalo que ocorrem nas hípicas e mobilizam expectadores e apostadores.

19 Quando fui morar na comunidade, recebi emprestados alguns móveis de um casal de amigos e contratei um desses fretes para o transporte. $O$ freteiro me cobrou $R \$ 5,00$ pelo serviço. 


\section{Múltiplas concepções de honra}

Boa parte das análises sobre a honra na literatura antropológica centrou-se em aldeias e sociedades camponesas. Em minha pesquisa, considerei como ponto de partida as análises de Pitt-Rivers e Peristiany sobre a "honra mediterrânea", as reflexões de diversos autores reunidas em coletânea organizada por Gautheron sobre a honra como "dom de si ou imagem de si" e, ainda, a investigação de Fonseca sobre as modalidades de honra numa vila popular de Porto Alegre. Estudos publicados a partir da década de 1990 lançavam dúvidas se ainda valeria a pena se falar em honra, considerando que a noção estivesse "doente" ou "degradada". Gautheron alertava para o risco de se banalizar a honra por uma extensão abusiva do sentido, considerando-se como tal uma exigência individual ou universal de dignidade. Parece-me, entretanto, que Pitt-Rivers está certo quando afirma que "a honra foi expurgada da língua, não do sistema simbólico". 20

Para analisar um universo de trabalhadores na mineração, propus desdobrar a noção de honra concebida a partir do estudo de aldeias camponesas em duas dimensões: a da "grande honra", mais voltada para as imagens que figuram nas representações idealizadas do heroísmo mineiro, e a da "pequena honra", correspondendo aos diversos pertencimentos locais e às insurgências nas interações cotidianas, com suas tensões e conflitos internos. Neste sentido, a "grande honra" encontra sua mais clara ilustração no caso dos mineiros franceses, pesquisados por mim num estudo de menor duração na região da Lorena, que abrigou a última mina de carvão da França (La Houve), fechada em 2004. Essa "grande honra" parte de uma "mitologia" criada em torno do mineiro de subsolo, com sua reverberação íntima mais ou menos entranhada nos sujeitos. ${ }^{21}$ No decorrer da pesquisa, percebi que uma abordagem sobre a honra a partir destafaceta encararia só parte da questão, correndo o risco de reforçar essa idealização, daí a observação de outras configurações que emergem nas narrativas, nas trajetórias individuais e nos pertencimentos coletivos, que, a meu ver, caracterizam as formas da "pequena honra". Ao conceber os termos de "grande honra" e de "pequena honra" inspirei-me no modelo de Redfield acerca da Grande e da Pequena Tradição, a partir de estudos em sociedades camponesas, e na forma pela qual as duas tradições interagem como processos complementares, viabilizados pela ação de mediadores..$^{22}$ Guardando uma alusão ao sentido original, tomei de empréstimo o modelo, transformando-o em "grande honra", de cuja construção participariam o Estado, as empresas, os partidos, a mídia, os sindicatos, os intelectuais e toda uma gama de agentes com poder sobre a opinião pública, e "pequena honra", correspondendo a uma diversidade de valores, crenças e práticas locais combinados entre si, com origem periférica em relação à centralidade representada pela "grande honra".

20 Ver: PERISTIANY, John; PITT-RIVERS, Julian. (orgs.). Honor y gracia. Madrid: Alianza Editorial, 1992; PITTRIVERS, Julian. “Honra e posição social”. In: PERISTIANY, John. G. (org.) Honra e vergonha: valores das sociedades mediterrâneas. Lisboa: Fundação Calouste Gulbenkian, 1965. p. 13-59; PITT-RIVERS, Julian. Anthropologie de l'honneur: la mésaventure de Sichem. Paris: Le Sycomore, 1983; PITT-RIVERS, Julian. "A doença da honra". In: GAUTHERON, M. (org.). A honra: imagem de si ou dom de si: um ideal equívoco. Porto Alegre: LP\&M, 1992. p. 17-32. Ver, ainda: FONSECA, Claudia. Família, fofoca e honra: etnografia de relações de gênero e violência em grupos populares. Porto Alegre: Editora da Universidade/UFRGS, 2000.

21 DESBOIS, Evelyne; JEANNEAU, Yves; MATTÉI, Bruno. La fois des charbonniers: les mineurs dans la Bataille du charbon 1945-1947. Paris: FMSH, 1986.

22 Ver: REDFIELD, Robert. "The social organization of tradition". In: POTTER, Jack M.; DIAZ, Mary N. and FOSTER, George M. (eds). Peasant society: a reader. University of California, Berkeley, 1967, p. 25-34. Ver, ainda: BURKE, Peter. Cultura popular na Idade Moderna: Europa, 1500-1800. São Paulo: Companhia das Letras, 1989, p. 51. 
Os estudos de Bailey sobre reputações contribuíram para desenhar os contornos teóricos da noção de "pequena honra", cujo valor se inscreve na vida ordinária. Segundo este autor, em pequenas comunidades, a pequena política da vida cotidiana de cada um está ligada às reputações, o que significa "ter um bom nome”, "evitar a desqualificação social”. Sugiro que a "pequena honra”, tal como a reputação, precisa do reconhecimento dos outros, mas está calcada num sentimento íntimo (que lhe corresponde ou lhe contradiz), enquanto que a reputação mantém o seu caráter de exterioridade. ${ }^{23} \mathrm{O}$ que passei assim a denominar como "pequena honra" é a combinação entre o prestígio que cada um obtém socialmente e a estima de si, seu próprio sentimento de dignidade, que tanto é alimentado por esse reconhecimento como o alimenta na esfera social. Todo o tempo evidencia-se uma tensão entre o prestígio e o desprestígio, o respeito e o desrespeito.

Em Minas do Leão, a noção que estou denominando de "pequena honra" se expressa, particularmente, nas manifestações de "orgulho" que não se limitam à profissão de mineiro (condição que pode ou não evocá-lo), mas que se esboça ainda no interior de outros liames - como o pertencimento a certa família, à origem rural, à posição social ou política, a determinada religião, a um time de futebol, etc. Outros termos evocados pelos interlocutores são a "consideração", o "respeito", dizendo respeito a laços sociais ou familiares, valores vistos como transmissíveis de geração a geração e que podem se relacionar com a posição ocupada na companhia no passado. Muitas referências são feitas à reputação, à importância de se ter amizades, crédito, de preservar o "bom nome", a estima dos outros e de evitar a desconsideração e o desrespeito. Formas de honra parecem estar em jogo ainda nas atribuições e/ou autoatribuições em torno do dom (usado geralmente por referência ao sagrado) e das habilidades e talentos (para o trabalho, o esporte, a política ou para a malandragem), que demandam o reconhecimento do grupo. ${ }^{24}$

Estudos antropológicos e sociológicos, bem como autobiografias operárias, têm feito eco a um tema que foi formulado por Bourdieu como sendo "a dupla verdade do trabalho", ancorada em suas dimensões objetiva e subjetiva, evidenciada pelo fato de que, não raro, há a percepção de um ganho subjetivo ligado ao próprio investimento no trabalho ou nas relações de trabalho. ${ }^{25}$ Como afirma Leite Lopes, ao analisar a dominação sobre os operários têxteis, esse "investimento" peculiar feito pelo trabalhador para adequar-se à sua profissão e também para reinventála, tornando suportável o trabalho fabril, dota-o de uma "honra" profissional. ${ }^{26}$ Ao prefaciar um dos escritos autobiográficos do operário francês Georges Navel, Géraldy destacava, por um lado, a narrativa em torno da satisfação extraída pelo trabalhador manual ao enfrentar as resistências da matéria: "É o esforço operário, o prazer deste domínio das mãos feito de um longo aprendizado e de pacientes sacrifícios". ${ }^{27}$ No outro extremo, estava a fadiga, o tédio e o sofrimento impostos pelo ritmo industrial. Pesquisas sobre camadas populares e sobre classes trabaIhadoras, em âmbito nacional e internacional, têm tocado nessas questões a partir

23 BAILEY, Frederick George. Gifts and poison: the politics of reputation. Oxford: Basil Blackwell, 1971, p.21. Na definição de Bailey (1971, p.4), a reputação não é uma qualidade que a pessoa possui, mas a opinião que as outras pessoas têm dela.

24 Em outros trabalhos, explorei o tema das equipes de futebol ligadas às minas.

25 BOURDIEU, Pierre. "La double vérité du travail”. Actes de la recherche en sciences sociales, Année 1996, v. 114, n.1, p. 89-90.

26 LEITE LOPES, José Sergio. A tecelagem dos conflitos de classe na cidade das chaminés. São Paulo: Ed. Marco Zero; Brasília: Ed. Universidade de Brasília, 1988, p. 23.

27 "C'est l'effort ouvrier, le plaisir de cette maîtrise de mains faite d'un long acquis et de patients sacrificies". Ver: GÉRALDY, Paul. “Préface”. In: NAVEL, G. Travaux. Paris: Gallimard, 2004, p. 7-14. 
de diferentes vieses. Entre mineiros de carvão, tanto o sentimento de honra como de desonra relacionados ao trabalho parecem situar-se no encontro de elementos relacionados tanto ao "gosto pela mina", ao jogo - incluindo aí as resistências, as malandragens, como também a dimensão do esporte, o apreço ao risco, à aposta e à adrenalina - como à revolta - significando as mobilizações de resistência, as greves, e a própria recusa em conceder valor a esse universo.

Meu interesse pelo que, posteriormente, me levou ao tema desta pesquisa foi despertado ainda em meus primeiros contatos em Minas do Leão (RS), entre meados e o final da década de 1990, quando trabalhava como jornalista. Vivenciei a vertigem de descer às minas de subsolo e travei os primeiros contatos com esses trabalhadores, alguns dos quais se converteram em meus informantes, posteriormente, na realização da etnografia. Na época, Leo, velho mineiro de carvão, ao me explicar sua ligação com a mina de subsolo, tecida ao longo de 35 dos seus mais de 70 anos de vida, me disse: "O carvão é como o mar, apaixona a gente". O seu relato continha não apenas a magia dos subterrâneos, mas também a dimensão das tragédias a que assistiu e a contabilidade dos companheiros que perdeu. Mostrava que o engajamento no mundo da mina - como aquele no mar - continha seus riscos, sortilégios e armadilhas, enfrentados cotidianamente pelos trabalhadores a partir de sua habilidade, de sua força e de sua coragem.

Essas imagens retornariam nas falas de outros interlocutores e passariam a povoar minhas reflexões. Escutei Zecão, mineiro ainda hoje em atividade na CRM, na época com 35 anos, refletir sobre o ofício: "Pra mim, o mineiro de subsolo é um herói”, definiu, referindo-se à trajetória do pai e do avô, que haviam trabalhado no Cadem e na Copelmi, e de quem ele havia herdado a profissão. Durante minha primeira etnografia, conduzida na mesma localidade, em 2003, o operário que me havia falado do herói disse-me a propósito do filme Germinal, uma adaptação cinematográfica da obra de Émile Zola: "Germinal é a história que meu pai contava, a história que eles viviam, entendeu?". Zecão se referia ao trabalho de crianças nas minas gaúchas e ao uso de cavalos para a retirada do mineral. O comentário estabelecia uma conexão entre a transmissão de valores familiares e a fonte literária que havia despertado meu próprio interesse por aquele universo.

Alguns anos mais tarde, num dia de chuva do começo de setembro de 2006, lá estava eu chegando a Minas do Leão (RS) para um trabalho de campo de mais longa duração a bordo de um caminhão de mudanças pintado de rosa-choque. Vi da boleia em que nos encontrávamos, eu, o motorista e outro funcionário da empresa de transportes que alguns moradores saíam à rua, atraídos pela curiosidade sobre a chegada de um novo morador. Na parte traseira do caminhão, eu levava alguns poucos móveis, equipamentos e utensílios para a temporada de seis meses em que moraria na casa alugada no centro da antiga vila mineira, próxima à Vila dos Freitas. Como projeto, pretendia estudar a construção social do heroísmo entre trabalhadores da mina subterrânea. Algum tempo depois, parecia-me que eu tinha ido procurar o heroísmo dos mineiros e encontrado mundos aparentemente mais domésticos.

A Mina de Leão I, a última exploração de subsolo na região, havia sido fechada quatro anos antes, em 2002, e, processado em certa medida o luto nos corações e mentes dos trabalhadores, as referências à mina pareciam terem sido suplantadas nas conversas cotidianas por questões familiares e de vizinhança, pelos conflitos sazonais na política, pela celebração dos esportes e jogos, pelas intensas e variadas procuras religiosas, assim como pelos embates das novas gerações em busca de emprego ou de uma ocupação. Percebi que à medida que se distanciava 
o "tempo da mina" de subsolo afloravam os outros mundos que teciam os sentimentos, valores e práticas dos moradores da cidade formada em torno da mineração - mesmo que uma exploração à flor da terra ainda se mantenha. Com o arrefecimento das emoções ligadas ao subterrâneo, emergiam outras realidades, de uma tessitura diversa e movente, que nos ajudam a desvendar como se forjaram as contradições em torno da mina.

Em Minas do Leão, ao me estabelecer em campo, construí relações que não eram apenas de uma pesquisadora estranha ao lugar, mas fui sendo inserida nas redes familiares, de amizade e de vizinhança. A partir dessas redes, tive um acesso privilegiado à vida privada de meus interlocutores. Havia uma mudança decisiva no cenário e eu desfrutava de novas condições de observação: esses fatores acabaram por provocar um deslocamento do objeto de pesquisa. De um lado, o fim da mina de subsolo como realidade e como possibilidade objetiva de ingresso no mundo do trabalho - figurando ainda intensamente nas memórias como referente simbólico, inspirando tanto amor como revolta ${ }^{28}$-, de outro, minha observação contínua daquele cotidiano, fizeram com que a minha primeira hipótese, em torno de um sentimento relacionado ao heroísmo da profissão, se revelasse insuficiente para dar conta tanto dos aspectos que conferem sentimentos de autoestima e dignidade aos meus interlocutores como daqueles que lhes ameaçam a reputação. Com a mina em funcionamento, essa capilaridade passaria um tanto despercebida pela "magia", pela força simbólica que ela exerce. O universo da mina, atravessando trajetórias individuais e coletivas, pode nos remeter a uma superinterpretação que ofusca outros aspectos. Um relativo apagamento de sua presença - a ausência-presença do luto - ajudaria a revelar a ressonância de universos percebidos mais facilmente no vácuo deixado por ela.

A pergunta que me fiz ao longo da pesquisa, mais especificamente do trabalho de análise e de interpretação dos dados obtidos em campo, é sobre o que gera autoestima, sentimento de orgulho e de dignidade para os trabalhadores e suas famílias, e o que é considerado como causador de desprezo, de desrespeito ou de desconsideração. Na condução das entrevistas, porém, nunca coloquei esta pergunta de forma direta. Primeiro, porque a própria questão surgiu mais da observação cotidiana do que por minha procura. Segundo, esse não era o meu ponto de partida. Além de percursos biográficos, eu investigava a percepção de meus interlocutores sobre o heroísmo relacionado ao trabalho na mina. Por meio da etnografia, de pesquisa documental e bibliográfica percebi que uma determinada face do sentimento de heroísmo era só uma das construções - embora importante e profundamente enraizada -, à qual estou me referindo como a "grande honra" relacionada ao mundo mineiro. Ela parte de uma mitologia criada em torno do mineiro de subsolo, com sua reverberação íntima mais ou menos entranhada nos sujeitos. Mas uma abordagem sobre a honra a partir desta faceta encararia só parte da questão, correndo o risco de reforçar essa idealização, daí a abertura a outras configurações que emergem nas trajetórias individuais e em pertencimentos coletivos, caracterizando as formas da "pequena honra" - em sua variedade e multiplicidade.

Nos relatos sobre a atividade na mina, encontra-se frequentemente o orgulho do "trabalho bem feito" 29 , da competência e da habilidade profissional

28 Nos relatos, a mina aparece tanto como a "grande mãe", a quem se deve "tudo", como também aquela que, pela exploração do trabalho, por acidentes e mortes, "levou tudo o que se tinha", fosse a disposição para o trabalho, a saúde, uma parte do corpo mutilado ou mesmo um ente querido.

29 Ver: HOGGART, Richard. As utilizações da cultura: aspectos da vida cultural da classe trabalhadora. Lisboa: 
apreendida na relação com companheiros de trabalho ou herdada de gerações de mineiros (gente que "sabia desde criança que o carvão era preto", como ouvi muitas vezes na Lorena francesa). Junto à "grande honra" que idealiza o trabalho mineiro, na vida cotidiana há formas nas quais a "pequena honra profissional" se apresenta, por exemplo, relacionada à conversão do trabalho a um estatuto de "arte" ${ }^{30}$, sobre a qual se colocam as competências técnicas apreendidas, o caráter de uma transmissão (como aprendiz ou como filho de mineiro), conformando uma dedicação que possui os contornos do "gosto", do "amor" pelo ofício. Essa modalidade de "pequena honra" ligada ao exercício primoroso da profissão pode reforçar as imagens grandiosas da "grande honra", conjugando-se eventualmente a uma honra familiar ao enfatizar uma hereditariedade na reprodução da atividade, a "patrilinhagem". ${ }^{31}$

Nessa comunidade, aspectos como a imagem e a estima de si, o orgulho, o dom, o reconhecimento, a consideração, assim como os atributos negativos - todos esses traços que demarcam a honra e traduzem uma reputação - afloram de forma privilegiada no discurso sobre si mesmo e sobre os outros. Verret mencionava o princípio de "visibilidade" que destaca um militante operário: a ideia de que "ele sabe falar", de que "fala bem". ${ }^{2}$ Ainda que em Minas do Leão essas emergências não estejam senão raramente ligadas a uma trajetória de militância, valoriza-se o domínio da palavra, a arte de se expressar. Quando se está tratando de relatos obtidos em segmento popular, há que se considerar o significado - simbólico e político - que o ato de "tomar a palavra" para falar de si e de seu mundo carrega para o narrador. Num universo em que as histórias de vida e de trabalho constituem a matéria-prima mais preciosa, os relatos biográficos tornam-se importantes instrumentos de pesquisa. ${ }^{33} \mathrm{Em}$ Minas do Leão, a realização de um grande número de entrevistas de caráter biográfico remeteu-me ao uso privilegiado de trajetórias como forma de melhor recompor a dinâmica encarnada pelos personagens. Os estudos sobre biografias e autobiografias operárias, além das próprias, têm atestado essa importância. ${ }^{34}$ Ao analisar trajetórias de trabalhadores, é sempre

Editorial Presença, 1973; LEITE LOPES, José Sergio. A tecelagem dos conflitos de classe na cidade das chaminés. São Paulo: Ed. Marco Zero; Brasília: Ed. UnB, 1988.

30 Sobre os "artistas" na usina de açúcar, ver: LEITE LOPES, José Sergio. O vapor do diabo: o trabalho dos operários de açúcar. Rio de Janeiro: Paz e Terra, 1976. Sobre o "pescador feito", ver: DUARTE, Luiz Fernando Dias. As redes do suor: a reprodução social dos trabalhadores da pesca em Jurujuba. Niterói: EdUFF, 1999.

31 ECKERT, Cornelia. Une ville autrefois minière: La Grand-Combe, étude d'Anthropologie Sociale. (Thèse Doctorat en Anthropologie Sociale, Université Paris V, Sorbonne, Sciences Humaines, Paris, 1991); e ECKERT, Cornelia. "Relato de uma pesquisa etnográfica na França". Revista do Instituto de Filosofia e Ciências Humanas, Porto Alegre, v. 15, p. 9-30, jul. 1992.

32 VERRET, Michel. "Biographies, militances, dictionnaires". In: DREYFUS, M., PENNETIER, C., VIETDEPAULE, N. (dir.). La part des militants. Biographie et mouviment ouvrier: autour du Maitron, Dictionnaire biographique du mouvement ouvrier français. Paris: Les Éditions de L'Atelier/Éditions Ouvrières, 1996, p.27-28.

33 Para Becker, a história de vida compartilha com a autobiografia "sua forma narrativa, seu ponto de vista na primeira pessoa e sua postura abertamente subjetiva". Ver: BECKER, Howard S. "A história de vida e o mosaico científico”. In: BECKER, H. S. Métodos de pesquisa em ciências sociais. São Paulo: Hucitec, 1993, p.102.

34 Ver: BURNETT, John; VINCENT, David \& MAYALL, David. The autobiography of the working class: an annotated critical bibliography. Londres: The Harvester Press, 1984. Estes autores (1984, p. xvii), por exemplo, observam que "todas as autobiografias representam uma espécie de triunfo sobre a adversidade": refletem e estimulam o crescimento da autorreflexão e do autorrespeito entre membros da classe trabalhadora. Ver, ainda: VERRET, Michel. "A honra de classe". In: GAUTHERON, M. (org.). A honra: imagem de si ou dom de si: um ideal equívoco. Porto Alegre: LP\&M, 1992; VERRET, Michel. "Biographies, militances, dictionnaires”. In: DREYFUS, M., PENNETIER, C., VIET-DEPAULE, N. (dir.) La part des militants. Biographie et mouviment ouvrier: autour du Maitron, Dictionnaire biographique du mouvement ouvrier français. Paris: Les Éditions de L’Atelier/Éditions Ouvrières, 1996. Ver: NAVEL, Georges. Travaux. Paris: 
bom se ter em mente o que escreveu Schwartz sobre o fato de que, num trabalho sobre a classe operária, deve-se manter distância crítica ao olhar que é tentado a descrever a cultura das classes populares como sendo uma "cultura mais pobre". Em seu estudo, ele sublinhava a dimensão dos desejos, das problemáticas e dos saberes dos nativos. 35

\section{Jango: "artes" e denúncias da mina como "ratoeira"}

Conheci Jango Freitas em 2003, numa visita à comunidade, e, desde então, ele converteu-se num de meus principais interlocutores na pesquisa. $O$ fato de que, em 2006, eu tenha ido morar na Vila Freitas, numa casa alugada de um parente dele e cuja transação contou com seu aval de que eu era uma pessoa "de confiança", contribuiu para estreitar ainda mais nossa relação. Eu já tinha estabelecido laços de amizade com toda a família. Jango, com 65 anos à época da nossa última entrevista, revelou-se um interlocutor expressivo tanto em relação às tragédias da mina como às suas jocosidades. Ele e seu irmão Antônio Manoel ${ }^{36}$ eram os filhos mais novos entre os 15 do carreteiro José Antônio Freitas, conhecido como Zeca Freitas. Viúvo duas vezes, o pai de Jango mudou-se de Rio Pardo para Minas do Leão em 1948, para trabalhar no transporte do carvão, tendo como "capital" cinco carretas e cerca de 80 bois mansos. O caçula Jango tinha seis anos de idade quando chegou à vila mineira.

Quando Zeca Freitas - cujo nome batiza um Centro de Tradições Gaúchas (CTG) na localidade - passou a trabalhar com agricultura e produção de leite, Jango teve sua primeira atividade: "Eu me criei aqui, vendendo leite: eu era leiteiro aí nessa vila". A imagem que ele guarda dos primeiros tempos é de uma vila com cerca de 300 casinhas de madeira pertencentes à companhia e que eram cedidas aos trabalhadores. Os planos familiares eram de que os filhos, quando crescessem, ajudariam o pai na atividade de transporte de carvão com carretas de boi, mas a estratégia foi frustrada devido à modernização do transporte rodoviário. Depois de um ano na atividade, a família Freitas começou a enfrentar a concorrência de caminhões, o que inviabilizou a continuidade no ramo. A alternativa foi o plantio de eucaliptos para fornecimento de madeira à mina. Mas era preciso encontrar trabalho para os filhos mais novos. Antônio Manoel e Jango foram empregados na mina. A própria contratação surgiu das boas relações de Zeca Freitas com a companhia.

Meu interlocutor referia-se à mineração como um setor "considerado", "respeitado" - fazendo menção a um valor central na educação de famílias com origem rural. Quando começou a trabalhar no DACM, em 1959, aos 17 anos, Jango atuava na superfície como ajudante de pedreiro e carpinteiro. Ele fazia consertos e reformas das casas da companhia cedidas aos trabalhadores. Mas essa atividade ainda não era considerada "uma profissão". Seu irmão, Antônio Manoel, mecânico da empresa, convidou-o para trabalhar com ele a fim de que aprendesse um ofício. Jango resolveu tentar, mas nunca se identificou com a atividade: "Porque eu

Gallimard, 2004; NASH, June \& ROJAS, Juan. He agotado mi vida en la mina: Autobiografía de un minero boliviano. Buenos Aires: Nueva Visión, 1976; MALVA, Constant. Ma nuit au jour le jour. Paris: Ed. Maspero, 1978; VISEUX, Augustin. Mineur de fond, Paris: Plon, 1991; MINTZ, Sydney. Taso, la vie d'un travailleur de la canne. Paris: Maspero, 1979.

35 SCHWARTZ, Olivier. Le monde privé des ouvriers: hommes et femmes du Nord. Paris: PUF, 1990, p. 55.

36 Um dos mineiros-jogadores que integraram o Atlético Mineiro F.C. 
nunca tive assim aquela vocação de mecânico, eu tenho até ódio de apertar os parafusos... (risos). Fui, fiquei três anos por lá e não aprendi nada (...)". Já estava há seis anos na empresa, ganhava um salário mínimo e continuava "sem profissão". O fato de que não fosse um "profissional" foi um argumento usado para lhe negar aumento.

Jango - Aí eu fui falar com ele: “Ô, seu engenheiro...”. "Não, não posso te dar aumento, tu não tem profissão”. Foi quando eu fui encarar a mina.

Julieta (a esposa) - Na primeira semana tu quis desistir...

Jango - Ah, claro, eu cheguei lá..., eu já era apavorado, eu já era apavorado da mina. (...) Eu tinha vontade de fugir, tu entende? Apesar que eu nunca tive contato nenhum com mina. Eu sempre trabalhei na superfície, no céu aberto. Báh... eu cheguei lá e me apavorei do... do... cheiro da mina, do gás, da fumaça da mina. Bem, não tem como não apavorar. Eu cheguei a pedir pra ir embora e aí a Julieta (sua noiva na época) sugeriu: "Não, tu vai experimentando, vai..." A Julieta me deu muita força sobre isso aí. Aí eu fui indo, fui indo, que depois eu acostumei com aquele ambiente da mina. Aí, graças a Deus, me animei com a mina, me dei bem e tudo. Sempre tive uma amizade muito boa na mina também.

Jango queria trabalhar no subsolo e aumentar seu salário porque tinha planos de se casar. Sua primeira função no subsolo foi como madeireiro, responsável pelo escoramento das galerias. "Na época, não tinha maquinário, era tudo manual. Transporte era tudo na base do carrinho. Então, ali o meu patrão se aposentou, eu passei a ser sota capataz de equipe, ${ }^{37}$ aí eu teria já uma porcentagem de $15 \%$ de vantagem na produção". Posteriormente, passaria a patrão de galeria, ${ }^{38}$ função gratificada em 30\% sobre a produção do grupo. Nessa época, a mina funcionava 24 horas por dia. O patrão de equipe comandava um grupo de seis homens nos trabalhos de extração do carvão, carregamento do mineral e escoramento da galeria. Jango recebia por produção. Tinha trabalhado "por conta da casa", como diarista, nos dois primeiros meses no subsolo. Depois disso, insistia com os capatazes:

\footnotetext{
"Seu Chico, me dá uma oportunidade aí, me bota na produção, na tarefa". "Ah, rapaz", os caras diziam pra mim, os caras quase morriam rindo, "tu recém faz um mês e pouco, dois meses que está aí e já quer trabalhar na produção? Tem gente aí que está esperando uma oportunidade faz um ano". “Tá, mas eu quero me casar!”, eu dizia. (risos) Eles achavam engraçado. "Tá, eu quero me casar, eu preciso ganhar bem, tenho compromisso em casa".
}

Entre as ocupações enquadradas como "diaristas" estavam as de operários que cuidavam da ventilação, dos que carregavam madeiras e dos que faziam serviços como bombeiros e cubeiros - estes últimos tinham de transportar para a superfície o tonel no qual os mineiros faziam suas "necessidades" na mina, esvaziálo, lavá-lo e repô-lo no subsolo. Os que recebiam "por produção", além do salário fixo, tinham o acréscimo de acordo com a produção da equipe. Isso, segundo Jango, gerava a "ganância" de trabalhar mais, a "vontade" de aumentar a produção e, consequentemente, o ordenado, pois se a equipe conseguisse encher 55 carros por dia ganharia bem mais do que se fossem apenas 35 ou 40 . Ele enfatizava que a mina "sempre foi um setor muito perigoso", um local de trabalho no qual durante

37 Capataz que comanda uma equipe pequena de trabalhadores.

38 Responsável pelo trabalho do conjunto dos mineiros em uma determinada galeria. 
muito tempo não havia nenhuma segurança. Além de ficarem agachados durante longo tempo, os mineiros não contavam com equipamentos de proteção. Nos pés, usavam alpargatas, enquanto que a cabeça era protegida por um frágil boné ou gorro. Jango contava que "trabalhava sufocado", respirando fumaça e cheiro de explosivos. Posteriormente, a ventilação foi aperfeiçoada e foram melhoradas as condições de segurança.

Então, melhorou pro mineiro. O mineiro já trabalhava de macacão, botininha, capacete, lanterninha. Nós, não, na nossa época era um calçãozinho, um lampiãozinho e pronto. Sem camisa, sem nada. (...) Além de tu não poder te levantar nunca, ficar em pé, ainda um gorrinho na cabeça... A gente batia, caía de costas, era tudo isso aí. Quando dava um desmoronamento e caía uma pedra, era fatal. (...)

Jango calculava que tenha perdido, em certa época, quase que um colega de trabalho por mês em acidentes como desmoronamentos, incêndios, choques elétricos e outros. Acreditava que muitas mortes eram devido à falta de atenção e de conhecimento dos colegas, mas a maioria era por falta de segurança da mina.

Eu me escapei assim de morrer várias vezes por segundos. Acho que eu sou um felizardo. (...) Quando tu vê que o perigo às vezes é traiçoeiro. (...) Perdemos vários colegas de serviço por esse motivo. A gente chegava num setor de trabalho, olhava assim, tu não imaginava que aquilo fosse uma ratoeira. A gente vinha trabalhar, quando via, caía uma pedra, 200 quilos, 500 quilos. É normal na mina. É uma ratoeira. (...) Eu perdi vários amigos. Mas amigos mesmo que poderiam ser considerados como irmãos. Eu ajudei a cavar, a desenterrar de pá um colega de trabalho meu. (...) Deu um desmoronamento em cima dele, eu acho que tava 30 mil quilos de material. E a gente se põe nessa situação... tirar um colega morto de trole. Eu sou um sobrevivente.

Ao contar essa passagem, Jango se emociona. Contou que o acidente que ocasionou a morte do amigo, em setembro de 1977, foi a tragédia que mais o chocou, que mais alterou o seu "estado nervoso". ${ }^{39}$ Sentia-se mal ao cavar para retirar o corpo do companheiro. Em seu relato, os perigos da mina eram descritos como "traiçoeiros", inesperados, de tal forma que o trabalhador no subsolo se via no interior de uma "ratoeira", evocando uma espécie de animalidade a que estariam sujeitos esses operários, como gente que vivia no limiar da condição humana. O uso do termo "sobrevivente" nos remete à imagem de uma guerra nas entranhas da terra. Outro momento em que se referia à "ratoeira" era ao mencionar o descaso na manutenção da rede elétrica no subsolo, com fios desencapados no meio do caminho. Em seus primeiros tempos de trabalho não havia ainda sido constituída a Comissão Interna de Prevenção de Acidentes (CIPA) na mina de Leão I. Recordavase que, no início, o elevador que dava acesso ao subsolo - chamado de "gaiola" - não tinha proteção lateral. "Subiam oito, dez homens em cima daquilo ali, que inclusive perdemos colega de serviço ${ }^{40}$ em cima daquele... Eu tinha muito medo. Eu, sempre quando embarcava, ia bem pro centro. Tinha medo de alguém me empurrar e eu morrer".

39 Sobre a questão do "nervoso" entre as classes populares, ver: DUARTE, Luiz Fernando Dias. Da vida nervosa nas classes trabalhadoras urbanas. Rio de Janeiro: Graal, 1986.

40 Ele se refere a Araceni Mendes Pereira, morto em dezembro de 1979. Segundo as informações em sua ficha funcional, o mineiro, de 31 anos, caiu no poço ao passar mal e desmaiar no elevador de acesso à mina. Em função deste acidente, notificações do Ministério do Trabalho exigiram da companhia a contratação de um engenheiro de segurança e a adoção de medidas de segurança na "gaiola". 
Eu tive muito medo na mina. Em primeiro lugar, eu tive medo de morrer na mina quando os meus filhos eram pequenos. Eu tava criando a minha família e tinha muito medo de morrer, deixar eles pequeninhos. Em segundo lugar, outra coisa que eu tinha muito medo assim... quando eu perdia um colega naquele setor. Passava ali 15, 20 dias com sestro, com nervosismo. Sei lá, estado nervoso. (...) Eu tinha medo, às vezes, no início, de passar ali. Parece que ia enxergar aquela pessoa, que a gente considerava, queria bem. Então, eu tinha medo. (...) Eu venci meu tempo na mina porque eu precisava muito, senão eu não vencia.

Para Jango, os subterrâneos ocultam muitos mistérios nas suas sombras. Ele formula assim sua definição: "A mina é uma caixa de segredos, que ninguém assim descobre o significado". A seu ver, Deus dá um dom para que cada um seja diferente do outro. A fantasmagoria da mina era evocada a partir dos relatos de companheiros que viam vultos na escuridão das galerias, que assistiam ao movimento de carrinhos de carvão na solidão da noite e que ouviam vozes e gemidos que só podiam ser de colegas mortos. "Pelo que contavam, existia muito mistério na mina". Não sabia dizer se era porque Deus era seu amigo e sabia que ele não teria coragem para ver "essas coisas", que o livrou desse "dom". Lembrava o momento que antecedia a um desmoronamento: "Um vácuo forte de vento cruzou por nós, parecia um tornado. Assustava a gente a 500 metros, levantando casca e poeira". Ficava atento aos pressentimentos.

Aconteceu comigo, quando eu era mineiro, de sair pro serviço e voltar pra casa. (...) Me parece que aquele dia ia ser impróprio pra mim, parecia que ia acontecer alguma coisa comigo. Eu tinha um receio. Me parece assim que eu tinha um aviso assim que eu não fosse... Algo acontecia comigo. Aí vinha, chegava lá e ia no posto de saúde e explicava até pros médicos (...)..

Nas suas explicações para o médico, a quem solicitava um atestado para faltar ao trabalho naquele dia, estava o "estado nervoso" diante da lembrança de "acidentes terríveis". Apesar dos perigos, via com simpatia a ideia de que os filhos fossem mineiros, se a mina ainda estivesse em funcionamento. Ele se referia ao fato de que a "lei do mineiro", que garante a aposentadoria aos 15 anos de serviço para quem atua nas frentes de extração, era muito respeitada. Além disso, "era a profissão da gente, de todos aí, era todo mundo em torno daquilo ali". Para ele, a saudade da mina convive com a tristeza pelos companheiros mortos em acidentes.

Tenho muita saudade da mina, saudade dos companheiros. E tenho muita tristeza da mina. (...) Eu vi acidentes terríveis na mina. Então, tem as horas boas que a gente recorda e também as horas ruins. Imagina: vir quatro quilômetros por baixo do chão empurrando num trolinho um companheiro de serviço...

Um dos acidentes que relata é um incêndio ocorrido no interior da mina, próximo ao depósito de explosivos, no qual morreram dois trabalhadores. $\mathrm{Na}$ ocasião, o capataz perguntou a Jango se ele poderia acompanhá-lo para tentar salvar os colegas. Assim, integrou a equipe de socorro. Enfrentaram grandes dificuldades. "A fumaça, aquilo assim era... mesma coisa que uma tempestade. Quando tinha condições de prender o fôlego, tudo bem, mas respirar lá era impossível”. O fogo foi combatido com o isolamento de áreas e a inversão da ventilação. Mas quando chegaram ao local os operários já estavam mortos. Pelos rastros, chegou à conclusão que "eles lutaram muito para não morrer". A esperança desses operários teria sido 
uma pipa que servia para armazenar água no subsolo. Teriam colocado essa pipa nos trilhos de vagonetes usados no transporte de carvão e empurrado até tentar encontrar uma saída no escuro, mas não conseguiram. "Então, eles sentaram um do lado do outro, e eles morreram assim numa posição de um querendo ajudar o outro. Ficou um deitado assim... e o outro com aquele gesto assim, agarrando. A coisa mais triste, a coisa mais triste do mundo!"

Observa-se a expressividade narrativa de Jango também na valorização das pequenas vitórias em "quedas de braço" com a hierarquia. Ele reclamava do fato de que recebia "zonas ruins" para a extração de carvão, em detrimento daqueles patrões de galeria que faziam média com os capatazes - evidenciando que a troca de favores era uma constante.

Antes de vivenciar episódios em que denunciou as más condições de trabaIho que favoreciam os acidentes, Jango havia disputado a eleição para MineiroPadrão. Tendo vencido as etapas em Minas do Leão e em Butiá, acabou perdendo em Charqueadas, onde era menos conhecido. Acreditava que essa disputa tivesse ocorrido em 1977. Ele me explicava que a indicação de seu nome, pela empresa, juntamente com a de outro colega, levava em conta seu currículo: o fato de ter, na época, quase 20 anos de serviço, ter participado de CIPAs, nunca ter recebido uma punição e, principalmente, de ser "amigo de todos". Lembrava que seu concorrente era mais velho, menos afeito às brincadeiras, e isso deve ter favorecido o "banho de votos" que deu nele. Depois das indicações feitas pela empresa, votavam todos os funcionários, inclusive os da superfície, quem atuava nas oficinas e na mineração a céu aberto. O voto não era obrigatório, mas ele calculava que pelo menos 300 dos 500 funcionários tivessem participado da votação. A vitória foi comemorada com jantar pago pelo sindicato dos mineiros.

Numa ocasião, perguntei a Jango se ele considerava que o mineiro fosse uma espécie de herói do trabalho. Ele recusou minha formulação, justificando com razões práticas, em torno dos ganhos salariais, a motivação para o trabalho.

\footnotetext{
Jango - Não, não considero [o mineiro] um herói, não. Eu considero o mineiro, como que eu vou dizer assim... ele tá numa profissão pra criar a família dele daquilo ali. A profissão que ele tem é aquela ali, é ser mineiro. E cai naquela rotina de mineiro e não sai, porque o ordenado às vezes compensa muito. Eles vivem uma vida tão tranquila... que o serviço é brabo e tu não considera, de tão bem que a gente ganha. Teve épocas assim, acho que eu te falei, os caras que vinham fazer o nosso pagamento, aqueles que eram do banco, eles perguntavam o que nós íamos fazer com o dinheiro. Ganhava mais do que os engenheiros, às vezes.
}

Jango considerava que a brincadeira era essencial para tirar "o medo da mina", salientando que o mineiro em geral era "muito moleque" e disfarçava o perigo com o bom humor. Ele próprio tornou-se famoso por suas "molecagens" e "brinquedos" no subsolo. Certa vez, um de seus filhos, Jefferson, ouviu de um cliente do banco em que trabalha como vigilante: "Báh, o teu pai era o mineiro mais sem-vergonha debaixo da mina. Tinha que fazer uma estátua prá ele, tinha que fazer uma estátua!" Reconhecimentos desse tipo não faltavam a Jango. Ele ria dessa "fama" e, orgulhoso da reputação, aproveitava para contar outras histórias. No relato, na fabulação ou na imitação, estava sempre renovando seu repertório, de tal modo que seu interlocutor hesitava, por vezes, em distinguir se o episódio era real ou inventado.

Aspecto importante da cultura dos trabalhadores de Minas do Leão, as 
brincadeiras ou relações jocosas ${ }^{41}$ eram uma contrapartida à dureza das condições de trabalho enfrentadas no subsolo. ${ }^{42}$ Boa parte das brincadeiras referidas em Minas do Leão fazia referência a temáticas sexuais, especialmente em torno das figuras do "corno" e do "viado", algo similar ao analisado por Duarte entre pescadores. ${ }^{43}$ Os apelidos funcionavam como uma espécie de batismo para o ingresso no subsolo. Os mineiros diziam que a alcunha "pega" quando a pessoa não gosta. "Se embrabecia, aí que o apelido pegava". As brincadeiras envolvendo o uso de palavrões e xingamentos faziam sentido na rotina do subsolo, mas não deveriam ser levadas para a superfície no entender de Jango: "Lá embaixo, no subsolo, nós éramos um tipo de gente, pela franqueza, pelo serviço corriqueiro. Agora, aqui em cima era muito diferente". Pelo menos esse, a seu ver, deveria ser o comportamento do "verdadeiro mineiro", enunciando uma espécie de metamorfose que devia ser vivida na passagem do subsolo à superfície. ${ }^{44}$ De acordo com ele, outros colegas "mais sem experiência da coisa (...) até no futebol saíam com alguma besteira", mas, no seu caso, se estava na superfície, a relação era de respeito. Havia também uma espécie de "código de honra" a regrar o sigilo em torno das brincadeiras masculinas, mas que era relativizado, de forma que, por vezes, as mulheres acabavam me revelando os temas das brincadeiras dos maridos no subsolo. Essas jocosidades envolviam jogos verbais nos quais as esposas dos companheiros figuravam como objetos de desejo. Esses jogos só eram considerados legítimos entre homens $\operatorname{casados}^{45}$ - embora pudessem ser aceitos solteiros que "não fossem passados", minimizando-se os riscos da brincadeira.

Os relatos evocavam também os trabalhadores que não participavam dos "brinquedos" e que reagiam violentamente aos apelidos, considerados como pessoas que "não foram domadas". Essa caracterização como "não domados", como mais próximos da natureza do que da "civilização" nas regras e na cultura dos mineiros, pareciam construir esses "outros" como trabalhadores menos confiáveis, menos socializados nas dinâmicas verbais e corporais e como portadores de um certo estigma. De acordo com Jango, tratava-se de pessoas oriundas das áreas rurais, que iam "com uma idade meio avançada para a mina" e que não se acostumavam com o clima de brincadeiras. Diante desses "baguais", uma estratégia

41 Termo usado em referência a Radcliffe-Brown (1973), quando trata dos "parentescos por brincadeira". Ver: RADCLIFFE-BROWN, Alfred Reginald. Estrutura e função na sociedade primitiva. Petrópolis: Vozes, 1973.

42 As brincadeiras são referidas por pesquisadores como: GROSSI, Yone. Mina de Morro Velho: a extração do homem. Rio de Janeiro: Paz e Terra, 1981; VOLPATO, Terezinha Gascho. A pirita humana: os mineiros de Criciúma. Florianópolis: EdUFSC, 1984; ECKERT, Cornelia. "Os homens da mina: um estudo das condições de vida e representações dos mineiros de carvão em Charqueadas/RS". (Dissertação de Mestrado em Antropologia Social, PPGAS/UFRGS, 1985); DUARTE, Luiz Fernando. "Identidade social e padrões de agressividade verbal em um grupo de trabalhadores urbanos". In: LEITE LOPES, J. S. (org.). Cultura e identidade operária. Rio de Janeiro: Marco Zero, 1987; LEITE LOPES, José Sérgio. O vapor do diabo: o trabalho dos operários de açúcar. Rio de Janeiro: Paz e Terra, 1976; ___ . A tecelagem dos conflitos de classe na cidade das chaminés. São Paulo: Ed. Marco Zero; Brasília: Ed. Universidade de Brasília, 1988; COMERFORD, John. Como uma família: sociabilidade, territórios de parentesco e sindicalismo rural. Rio de Janeiro: Relume-Dumará, 2003.

43 Duarte abordou os padrões de agressividade, os duelos verbais nos quais predominavam os temas do futebol e do sexo entre pescadores de Jurujuba (RJ). Ver: DUARTE, Luiz Fernando. "Identidade social e padrões de agressividade verbal em um grupo de trabalhadores urbanos”. In: LEITE LOPES, J. S. (org.). Cultura e identidade operária. Rio de Janeiro: Marco Zero, 1987.

44 Volpato afirma, igualmente, que embaixo da mina havia brincadeiras, humor e relações jocosas, mas na superfície esse comportamento ficava para trás. Ver: VOLPATO, Terezinha Gascho. A pirita humana: os mineiros de Criciúma. Florianópolis: EdUFSC, 1984.

45 Uma brincadeira similar é registrada por Eckert entre mineiros de Charqueadas. Ver: ECKERT, Cornelia. "Os homens da mina: um estudo das condições de vida e representações dos mineiros de carvão em Charqueadas/RS”. (Dissertação de Mestrado em Antropologia Social, PPGAS, UFRGS, 1985). 
adotada por ele era contar piadas para ver se "amansavam". Mencionava dois colegas da mina que nenhum investimento conseguiu "domar": um deles tinha o apelido de Galo Amarelo (porque havia dado um galo dessa cor de presente ao chefe). Em mais de um caso, segundo os comentários, o destino dos "não domados" revelou-se trágico, como o do mineiro cujo apelido era "indizível" e que teria se matado depois de atirar na própria esposa. O relato era seguido por um comentário: "Ele se deu mal: a mulher não morreu, existe até hoje". Outro interlocutor arriscava um palpite: "Acho que ele se matou por causa do apelido". As narrativas revelavam formas de controle social não apenas sobre os "não domados", mas também sobre os "malandros" que se excediam, gabando-se de forma exagerada de suas aventuras. ${ }^{46}$ As narrativas mencionavam ainda os embates corporais, as chamadas "tundas de casca", nas quais se alternavam os papéis de agressor e vítima, numa espécie de duelo no qual lançavam mão de cascas de eucalipto, usado para sustentação do teto no subsolo. Os mineiros utilizam expressões como "peleias", "brigas", remetendo ao ideal de masculinidade neste universo.

\section{O percurso de Marino: das lides rurais para a mina}

O ex-mineiro Luiz Marino, com 68 anos à época de nossa entrevista, conhece tanto as lides agrícolas como as do subsolo da mina. Nascido na localidade de Porto do Conde, no município de São Jerônimo, filho de agricultor, é oriundo de uma família de 13 filhos - oito homens e cinco mulheres. Começou a trabalhar aos seis anos de idade, ajudando o pai e os irmãos em plantações de eucalipto. Depois disso, a família foi trabalhar numa granja de arroz e, aos sete anos, Marino tornou-se o cozinheiro de um grupo de 15 a 20 homens. Além da comida, fazia um bolo para cada um e café - merenda que era transportada para a lavoura em latas de banha vazias. A cada nova atividade, a família ia se mudando, como "cigana". Seu pai conseguiu trabalho numa carvoaria que produzia carvão vegetal; depois, a família se empregou no corte de mato, enfardando a casca da acácia. TrabaIhavam no local entre 80 e 100 cortadores de mato. Com essa rotina, os filhos não foram para a escola. O pai chegou a contratar uma professora para ensinar às crianças, mas isso durou poucos meses. Marino aprendeu rudimentos de português e matemática, mas não aprendeu a ler e a escrever.

Já era um "homem feito" quando enveredou para a profissão de ferroviário e, depois, tornou-se mineiro. Em 1962, aos 22 anos, soube que precisavam de operários na Viação Férrea. Trabalhou ali durante dois anos. Recordava-se que, no início dos anos 1960, houve uma greve de mineiros organizada pelos trabalhadores do Cadem: "Eles queriam proibir a gente de trabalhar, achavam que estávamos furando a greve". Marino argumentou: "Eu não sou da firma de vocês, vocês são de uma, nós de outra". Lembra que a polícia havia sido chamada para garantir o funcionamento dos trens. Foi nesse período que ele descobriu que ganharia mais trabalhando na mina do que na ferrovia. Com a ajuda de um engenheiro, conseguiu uma vaga de operário no subsolo da mina administrada pelo DACM. No primeiro dia nas galerias subterrâneas, pensou em desistir: "Achei horrível! Cheguei lá pra tirar as contas". Lembrava que quando desceu pela primeira vez ao subsolo, sentiu "muito medo", explicando que quando a pessoa baixa ao subsolo, "perde

46 A brincadeira apelidada de "carrasco da mina" diz respeito a um ritual de simulação de castração no interior da mina, que serviria para coibir esses excessos, vividos e/ou narrados, daqueles que "gostavam de se gabar, de contar vantagens", principalmente sobre conquistas amorosas. 
um pouco o sentido". No começo, pensava: “Isso aqui é um inferno, não é vida”. Ouvindo os conselhos de mineiros mais experientes, permaneceu na atividade. Trabalhou inicialmente como ajudante, acompanhando o "patrão" 47 da galeria na preparação dos explosivos. Inicialmente, ficava apavorado com as explosões. Precisou aprender a se orientar para não se perder nas galerias que facilmente se transformavam em labirintos. Com o tempo, começou a achar que o trabalho "era coisa boa": "Eu gostava e gosto da mina". O que mais o agradava, como a outros, era "o cheiro da mina".

Uma das dificuldades que Marino enfrentou foi a cultura das malandragens e provocações: "O agricultor, logo que chega, sente muito, porque tem brincadeira desde o começo". O que mais o incomodava eram as humilhações infligidas aos companheiros. Certa vez, viu três mineiros batendo num colega negro e lhe dizendo: "Tu tem que acender o cigarro na nossa boca". O mineiro que apanhava pedia perdão aos outros. Marino não gostou daquilo e interveio: "Vocês larguem ele porque ele não é escravo! É porque ele é preto? Não me batam nele!”. Ameaçou atingir os colegas com o lampião, afirmando que era solteiro e que não tinha medo de ser mandado embora da empresa. Os outros deixaram o colega em paz. Em meados dos anos 1960, muitos mineiros desciam armados de facas e revólveres para a mina. Usavam as facas para cortar estopim. Já o revólver servia para que se sentissem mais homens, mais "valentes". Depois, a segurança se tornou mais rígida e o ingresso com armas foi proibido. O risco de aceitar as provocações e encarar uma briga era o de "ganhar as contas", ser demitido. Numa ocasião, depois de um enfrentamento com alguém que havia lhe "desrespeitado", Marino teve o seu cartão-ponto apreendido. Foi recebido com deboche no escritório:

\footnotetext{
- "Soube que o senhor é meio valente. Andou brigando debaixo da mina..."

Marino - Se o senhor me ofender, salto este balcão e lhe quebro a cara! - "Então, é valente mesmo!?"

Marino - Com a minha razão, sou!

- "Ninguém vai te botar pra rua. Tu nós não podemos te largar. Tu é caprichoso no serviço e precisamos de operários. Se quebrar a cara de outro tu não vai pra rua. Tu vai trabalhar e, quando houver alguma coisa, já sei o que se passou".
}

Pode-se notar as referências aos valores da "valentia", ao "ter razão", mas também a importância atribuída ao trabalhador "caprichoso" em sua atividade. A valentia é um dos valores presentes na honra masculina local, mas tal construção da masculinidade diz respeito mais diretamente ao que estou chamando de "pequena honra tradicional ou de origem rural”. Ela contrasta com os modos de socialização na cultura operária da mina de subsolo, marcada pela flexibilidade e pela malandragem. O que garante a permanência de Marino na empresa, para além da necessidade de mão de obra, é esse reconhecimento por parte das chefias de que se trata de um operário dedicado ao ofício. Seu temperamento esquentado - que poderia Ihe render a demissão - é tolerado em nome do seu valor como trabalhador. A relativa oposição entre valentia e dedicação ao trabalho estava presente em inúmeros relatos envolvendo personagens considerados "brigões". O fato de que fossem "muito trabalhadores" fazia com que os excessos fossem tolerados.

Antes de ir trabalhar na mina, Marino era capaz de iniciar uma briga se alguém o chamasse de "cunhado", por exemplo, ofendendo sua moral por referência às

47 Capataz que coordena os trabalhos numa galeria. 
suas irmãs. ${ }^{48}$ Mesmo depois, uma observação desse tipo seria encarada por ele como um insulto; seus brios exigiam que ele fosse tirar uma satisfação do provocador. Numa ocasião, chegou ao subsolo e encontrou um grupo de operários falando de sua namorada, com o irmão dela participando da conversa. "Eu vi e não gostei", conta ele. Depois, descobriu que era uma brincadeira dos colegas, que sabiam que, por ser novato, ele "ia embrabecer". Numa ocasião, o grupo mentiu que outro colega estava falando mal dele. Ao procurar o acusado, Marino já foi avisando: "Vou te dar uns tapas porque tu tá falando de mim". Um dos conflitos que ele teve foi com operário que "era muito passado":49 quando entrava na "gaiola"50 para subir à boca do poço xingava os colegas com palavrões. Numa ocasião, um grupo jogou óleo queimado no rosto do provocador e ele acabou perdendo o dia de trabalho. Mais tarde, ele e Marino encararam a coisa como um duelo: uma briga foi "tratada", com local e horário marcado e com direito a plateia. Para se precaver, Marino botou uma pedra no bolso do casaco e deixou o casaco sobre o ombro. Esperava que o outro o atacasse para revidar. Como o adversário ficou parado, desistiu da luta. Tempos depois, soube que o sujeito foi preso por matar a filha e espancar a mulher.

Por levar os desentendimentos a lutas corporais, Marino foi ganhando fama de "brigão". Sua esposa, Maria, que participava da entrevista, justificou que o marido tinha sido "criado pra fora", "tinha outros costumes". Sua família de origem tinha uma moralidade austera, mas nem por isso deixava de ser alegre. Numa época, o pai de Marino manteve um salão de baile em casa, que funcionava no quarto dos filhos - nessas ocasiões as mais de dez camas eram recolhidas e os músicos da família, que eram muitos, punham-se a tocar algum instrumento: violão, gaita, pandeiro etc. Marino e um dos irmãos formaram uma dupla sertaneja, a exemplo de outras que faziam sucesso na região. Meu interlocutor lembra-se que seu pai "era o mais bailarino", "era um artista". Ele promovia danças em frente ao espelho e brincadeiras nas quais participavam a família, parentes, amigos e vizinhos. Entretanto, nessas reuniões imperava o "respeito". No período como ferroviário, Marino integrou uma equipe de futebol de trabalhadores que se reunia em torno de um time ligado à família Fonseca, portando as cores vermelha e branca. Ele se recordava que havia muitos "morenos" na equipe, ligados àquela família, e que vários dos jogadores trabalhavam na lavoura. Segundo ele, a convivência entre brancos e "morenos" era boa: "Não se fazia conta das cores".

Do ponto de vista dos mineiros malandros, como Jango, esses trabalhadores que vinham do meio rural, como Marino, eram considerados "xucros", "quase uns animais" porque levavam tudo "na ponta da faca" e não sabiam tolerar uma brincadeira. Com o tempo, a maioria acabava sendo "domada" ou "domesticada" embora houvesse os que continuassem reagindo com violência às caçoadas. Nessas provocações, diferentemente do padrão tradicional estudado por Pitt-Rivers, em geral só um dos lados considerava seriamente a querela. Tratava-se de jogos distintos nos quais cada parte tomava o outro por antagonista, mas o que para um era desrespeito, desafio que merecia uma resposta violenta, para o outro era performance para fazer rir - quanto mais se embravecia o adversário, maior era a graça do jogo. Marino, que na linguagem dos colegas foi sendo "domado" ao longo do tempo, quando deixou de ser "novato" tornou-se "arriado", "inventor

48 Cabe lembrar a análise de Pitt-Rivers $(1965,1983)$ sobre os contextos nos quais a honra de um homem poderia ser ofendida com uma referência à sua irmã, filha, mãe ou esposa.

49 O termo, segundo o Dicionário Aurélio, significa atrevido, saliente, confiado.

50 Elevador da mina. 
de brinquedo e de piada", segundo ele mesmo contava. Trabalhava na mina quando, em 1969, casou-se com Maria, também filha de agricultor. Depois de casado, teve de enfrentar outro tipo de brincadeiras: os colegas queriam saber sobre sua relação conjugal. Uma provocação comum era: "Vai pro serviço? Esta noite vou passar na tua casa". Mas, a essa altura, ele já havia se acostumado com as provocações.

Como outros mineiros, que se referem aos "segredos" do subsolo, Marino acredita que a mina guarda "alguma coisa" dos companheiros que morreram ali. Relatava que, às vezes, ouvia o movimento "deles" e, quando olhava, não via ninguém. "Eu tinha muito medo, sentia medo da mina". Esse sentimento, no entanto, não o impedia de, quando já era veterano na profissão, promover sustos nos companheiros de trabalho, explorando justamente o temor da fantasmagoria da mina. Numa ocasião, ficou dependurado num prumo que segurava o teto da mina, no escuro, e quando passaram alguns companheiros, imitou uma voz do outro mundo para pedir-lhes fogo para acender o lampião. Foi uma gritaria. Enquanto os outros corriam, apavorados, ele fazia um barulho arrastando o lampião. Embora se servisse desses ingredientes para fazer suas brincadeiras, afirmava que, para ele, "não era invenção", acreditava que as almas dos colegas mortos realmente se manifestassem no interior das galerias.

Marino trabalhou no subsolo durante 21 anos. Foi madeireiro, transportador e ajudante de tocador de carros. Por vezes, fazia horas a mais, chegando a trabalhar três turnos num só dia para aumentar o seu ordenado. O ex-mineiro acredita deverse à sua sorte e à sua devoção a Deus o fato de não ter sofrido acidentes na mina. Mas sua saúde sofreu danos: ele contraiu a pneumoconiose ${ }^{51}$. Ingressou com uma ação na Justiça, mas não teve êxito, pois o nível de comprometimento dos pulmões era considerado insuficiente para a indenização. ${ }^{52} \mathrm{~A}$ seu ver, a empresa "tapeava muito essa parte de carvão no pulmão", distorcendo os resultados. Sua mulher fornece a explicação: “É porque o médico era da firma e não do operário, então ele não podia ir contra a firma". Citando o nome de um médico da companhia, Marino mencionava: "Pra mim ele dizia: 'Tá tapado de carvão o teu pulmão'. Mas o dinheiro mandava muito... o doutor vai lá e molham a mão dele". Considerando as condições do subsolo, perguntei-lhe se havia "heroísmo" no trabalho do mineiro. Quem respondeu foi Maria: "Não é por heroísmo, é por necessidade, porque só tinha aquilo ali". Marino preferiu destacar o seu envolvimento com o ofício: "No fim, até gostava do trabalho". Às vezes, ainda sonha que está na mina. Se as lembranças difíceis então presentes, também está lá, recorrente, o "gosto" pela mina.

Meu interlocutor recordava-se de greves ocorridas em seu tempo de trabaIho. Como era madeireiro - operário que faz o escoramento do teto das galerias -, era liberado pelo sindicato para "baixar" à mina mesmo durante as paralisações. Mas, em outra situação, se o sujeito fosse, nos termos que adota, "um bom trabalhador" e quisesse "fazer tudo direitinho" e furar a greve, era chamado de "carneiro" pelos companheiros. Marino chegou a fazer parte de uma comissão que foi a Porto Alegre discutir questões salariais com a direção da empresa. Os madeireiros eram pagos por tarefa e seu salário era calculado com base em uma tabela de

51 Doença pulmonar decorrente da inalação de poeiras minerais e orgânicas em suspensão nos ambientes de trabalho. Ela provoca perda da capacidade de expansão nos pulmões e fibrose. Além da pneumoconiose, essa poeira pode provocar também antracose, quando o carvão contém ao alto teor de cinzas.

52 De acordo com a legislação vigente no período, o mineiro só tinha direito à aposentadoria por invalidez se perdesse $50 \%$ de sua capacidade pulmonar, o que equivale ao funcionamento de um dos pulmões. Sobre este aspecto, ver: Ver: ECKERT. “Os homens da mina”, p. 339-345. 
pontos que diziam respeito à produção realizada: por exemplo, a colocação de uma barra valia sete pontos, de um pau, dois pontos, de um prumo, três pontos. Uma crise se formou quando um engenheiro alterou essa contagem dos pontos e os salários dos que recebiam por tarefa sofreram redução. A categoria se rebelou e entrou em greve. Na ocasião, Marino deu uma entrevista a uma rede de televisão criticando a direção da empresa. O diretor não gostou das críticas e, segundo seu relato, cobrou-lhe satisfações durante a reunião na sede da empresa.

\footnotetext{
- “Eu ouvi aí, tu pisou no meu pé!" - disse-lhe o diretor.

Marino - Doutor, eu falei a verdade. Eu Ihe levo lá embaixo [no subsolo] pro senhor ver que não estou faltando com a verdade. (...) Com esta tabela, não podemos tarefear. (...) Se tiver nela a assinatura do diretor da firma, eu quero que me dê as contas sem direito a nada!
}

A suspeita do mineiro era que o engenheiro local tivesse alterado a tabela sem o conhecimento da direção da empresa e, por isso, ele bancou a aposta na qual colocava em jogo o seu emprego. Preocupado, o presidente do sindicato alertou-o: "Olha, se tiver assinatura do diretor, tu vai pra rua". Segundo seu relato, ao conferir o documento, o diretor percebeu que a tabela era "fria" e teve que dar razão ao operário. O diretor teria dito: "Mas isso é uma pouca vergonha! Cadê a tabela que eu fiz na época?", "Consumiram com ela”, foi a ousada resposta do trabalhador. Marino me explicava que a queda nos salários dos madeireiros tinha sido grande: na tabela anterior, sua produção mensal somava entre 15 mil e 20 mil pontos; com a nova, mal atingia 5 mil pontos. Nesse episódio, os trabalhadores venceram a queda de braço. O que se destaca do seu relato é sua diligência e coragem para enfrentar a hierarquia e para expor-se ao risco de uma aposta como aquela. Ao longo de sua narrativa, evidencia-se o seu orgulho pelo engajamento numa discussão que acabou por trazer benefícios aos colegas. O mérito de discutir com a chefia e ainda ter razão - provando que está "com a verdade" - enaltece sua dignidade como trabalhador.

Após a aposentadoria, em 1983, Marino voltou a trabalhar na agricultura. Arrendou terras, onde plantava milho, aipim, moranga e criava vacas e porcos. A casa onde a família mora, de alvenaria, foi construída com o dinheiro que obteve com estas atividades. Antes, tinha adquirido da companhia uma casa de madeira, que foi substituída pela atual residência. Na época da pesquisa, mantinha apenas uma vaca de leite, que ordenhava todas as manhãs atravessando uma rua sem calçamento para ir ao terreno em frente. Um aspecto que lhe orgulhava era o fato de que seus filhos receberam uma escolarização mais longa do que ele mesmo (que não aprendeu a ler e a escrever) e do que a esposa (que estudou até a $5^{\text {a }}$ série). A filha cursou faculdade de História e atuava como professora. Os três filhos homens são mecânicos formados pelo Senai, dois deles com o ensino médio completo. Mesmo com a formação, um dos rapazes estava desempregado.

Nos últimos anos, Marino mantinha uma atividade peculiar. Do ofício nas profundezas da terra passou a dedicar-se às profundezas humanas, atuando como adivinho. Capaz, segundo me contava, de ver o que se passa no interior das pessoas, previa o futuro de quem o procurava e oferecia conselhos para superar obstáculos e dificuldades. Costumava receber a clientela numa salinha nos fundos de um supermercado na cidade vizinha. Para ele, não se tratava de um trabalho (embora os consulentes Ihe oferecessem alguma remuneração), tampouco de um engajamento religioso. Marino contou que essa capacidade o acompanhava desde criança, quando morou em lugares onde havia "assombros", no meio rural. Se 
alguém deixasse uma ferramenta do lado de fora da casa durante a noite, como um machado, "eles" iam cortar lenha; se deixasse o pilão, "eles" iam socar arroz. O menino ficava escutando os sons produzidos pelas almas do outro mundo nas suas lides ao redor da casa. Quando nos encontramos, durante a pesquisa, continuava a ver "formas que não eram humanas".

\section{Considerações finais}

Meu propósito, neste artigo, foi analisar o modo como determinados valores se expressam no cotidiano de uma comunidade erguida em torno da mineração de carvão no Rio Grande do Sul. Num universo marcado por valores urbanos e rurais, com seus trânsitos e misturas, considero que os sentimentos nutridos pelos trabalhadores em relação à sua atividade profissional, à sua identidade e aos seus pertencimentos sociais se articulam em diferentes formas de honra, em duas dimensões: uma relacionada à imagem heroica do mineiro de subsolo, construída historicamente em diferentes lugares do mundo, com suas similaridades e suas peculiaridades, que trato aqui como sendo a "grande honra" da profissão; e uma miríade de formas de "pequena honra", que se relacionam ao orgulho derivado tanto do trabalho propriamente dito como também de ações excepcionais na rotina da atividade de mineração, vistas como "corajosas" ou dignas de mérito, assim como aos universos que atravessam seu cotidiano, sejam os da militância sindical ou política, do engajamento religioso (ou das lides com o sobrenatural), seja o dos jogos, compreendendo aí as disputas esportivas, as apostas e as artimanhas de resistência à disciplina industrial, com contornos de "malandragens" ou de "brinquedos". Não foram muitas as vezes em que, durante o trabalho de campo, escutei a palavra honra ser mencionada, mas observei a recorrência dos termos “orgulho", "respeito”, “consideração”, denotando traços de uma honra tradicional de origem rural, que disputa espaço com a cultura operária.

Em minha pesquisa, sugiro que a honra profissional pode revelar-se pela afirmação dos valores do esforço e da competência técnica, encarnando uma intensa dedicação à atividade. Mas a habilidade, o dom de que se orgulha o mineiro pode estar relacionado não ao trabalho, e sim a formas de esquiva da disciplina industrial, mais exatamente a uma "pequena honra da malandragem", que compõe intensamente a cultura operária local. A valorização da astúcia, da esperteza e da ousadia pode entrar em contradição com outros valores morais presentes na sociedade local. Mas tais deslizamentos são, muitas vezes, justificados e legitimados pelo estabelecimento de outra moral, mais voltada às insurgências da vida prática e que leva em consideração os aspectos relacionais e o contexto em que tais lógicas operam. 